\title{
Perempuan dan Pembangunan Sektor Pertanian
}

\author{
Tutuk Ari Arsanti (Tutuk.arsanti@staff.uksw.edu)
}

Fakultas Ekonomika dan Bisnis UKSW

\begin{abstract}
The importance of prividing capacity women farmer in the agricultural sector bring a great impact on the development of the Indonesia's agricultural sector. This articles written to give a description of how the role of women in the development of the agricultural sector. A qualitative approach trough a method of participation action reseacrh used to obtain the image and problem solving faced. It will provide understanding in more well of potential for development agriculture in various line including potential for development entrepreneurship based agriculture by women. This research result indicates that the woman's role in efforts to improve the development of the agricultural sector through the development of entrepreneurial-based agriculture is very high. The importance of increasing the capacity of peasant women in the agricultural sector to be very needed in order to the development of agriculture especially for smal-medium scale of farming.
\end{abstract}

Keyword: Agricultural Sector, Women Farmer, Entrepreneurship

\section{PENDAHULUAN}

Sektor pertanian menjadi salah satu sektor yang masih mendominasi perekonomian Indonesia (Statistik Koperasi, 2005). Sektor pertanian selama ini masih memegang peran strategis dalam perekonomian Indonesia sehingga perhatian dan pengembangan sektor pertanian sudah semestinya dilakukan oleh banyak pihak baik pemerintah maupun masyarakat luas. Peran tersebut semakin nampak dari kemampuan sektor pertanian dalam berkontribusi terhadap pendapatan Indonesia, termasuk dalam penyerapan tenaga kerja (BPS). Potensi sektor pertanian yang sangat besar tersebut dalam kenyataannya belum diimbangi dengan kualitas SDM yang yang memadai untuk mencapai produktivitas sektor pertanian yang lebih tinggi. Persoalan klasik yang dihadapi pada sektor ini nyatanya masih senantiasa menjadi tantangan dalam mengembangkan sektor pertanian Indonesia kedepan. Secara makro sejumlah persoalan yang senantiasa dijumpai antara lain menurunnya kualitas dan kuantitas lahan pertanian, rendahnya teknologi pertanian tepat guna, NTP yang rendah dan kesejahteraan keluarga petani yang rendah memberikan gambaran akan sejumlah aspek kunci yang perlu dikembangkan dalam sektor pertanian seperti aspek 
SDM, kelembagaan dan produk pertanian. Pengembangan aspek-aspek kunci dalam sektor pertanian tentunya akan membawa dampak yang besar terhadap optimalisasi sektor pertanian dalam pembangunan perekonomian Indonesia.

Pengembangan aspek SDM dalam sektor pertanian menjadi kunci dalam pembangunan sektor pertanian dalam jangka panjang. Data Bappenas (2006) menunjukkan bahwa rendahnya kualitas SDM pertanian seiring dengan rendahnya tingkat produktivitas sektor pertanian. Kondisi tersebut membawa dampak lebih luas pada kemampuan sektor pertanian untuk mengembangkan berbagai inovasi yang mengarah pada peningkatan produktivitas pertanian. Kemampuan untuk berinovasi seharusnya menjadi dasar yang kuat dan sangat dibutuhkan dalam mengembangkan usaha (Freel \& Harrison, 2006) serta dalam pertumbuhan ekonomi (Huggins, 2001; Bougrain \& Haudeville,2002). Melalui peningkatan kapasitas para petani dalam mengelola pasca panen dan berinovasi untuk mengolah produk turunan pertanian dapat memberikan peluang usaha di bidang pertanian yang pada akhirnya dapat berkontribusi lebih besar terhadap perekonomian Indonesia. Hal tersebut dibutuhkan mengingat gambaran sektor pertanian Indonesia masih jauh dari daya saing yang tinggi dan melekatnya gambaran kemiskinan dalam sektor pertanian menjadikan ancaman dalam pembangunan sektor pertanian Indonesia dalam jangka panjang.

Peningkatan kapasitas perempuan sebagai bagian penting dari SDM sektor pertanian masih belum banyak tergarap dengan optimal. Berbagai upaya yang dilakukan untuk meningkatkan akses informasi sebagai sarana akuisisi pengetahuan para petani masih belum banyak melibatkan kaum perempuan di dalamnya. Budaya lokal yang menempatkan perempuan sebagai "konco wingking" menjadi hambatan tersendiri dalam penyebarluasan informasi dalam rangka peningkatan ilmu pengetahuan oleh petani perempuan pada sektor tersebut. Disadari bahwa peran perempuan dalam pertanian sangat besar pada kenyataannya, sebagian besar aktivitas pertanian senantiasa melibatkan perempuan didalamnya mulai dari penyiapan bibit, penanaman dan perawatan bahkan sampai pada masa panen perempuan mempunyai peran yang besar didalamnya. Dengan demikian peningkatan kapasitas petani perempuan dalam pembangunan sektor pertanian Indonesia menjadi sangat strategis. Peningkatan kapasitas petani perempuan sangat dibutuhkan mengingat sektor pertanian mempunyai daya serap terhadap tenaga kerja informal yang sangat tinggi dan dapat diisi oleh para petani perempuan. Dalam hal inilah peran perempuan dalam pembangunan sektor pertanian dan perekonomian Indonesia menjadi sangat penting. 


\section{KERANGKA TEORI}

\section{Perempuan dalam Sektor Pertanian}

Pengembangan SDM yang berkualitas merupakan antisipasi kesiapan membangun masyarakat berbasis pengetahuan dan menjadi prasyarat keunggulan bersaing pada abad 21 (Setiarso, 2007). Lebih lanjut, human development report (2006) menunjukkan bahwa terdapat korelasi positif antara $\mathrm{R} \& \mathrm{D}$ dengan pendapatan perkapita suatu negara, artinya bahwa dibutuhkan investasi di bidang SDM dalam setiap pembangunan perekonomian suatu negara. Peningkatan kualitas SDM tentunya menjadi pondasi penting dalam rangka pembangunan di segala bidang termasuk dalam pembangunan sektor pertanian. Peningkatan produktivitas melalui kemampuan berinovasi pada sektor pertanian terletak pada kapasitas yang dimiliki oleh SDM pada sektor pertanian. Kementerian Pertanian dalam liputannya di sebuah media nasional (2014) memperkirakan ada sekitar 50\% perempuan Indonesia yang terlibat dalam pembangunan sektor pertanian. Lebih lanjut dijelaskan bahwa dari 23 juta kepala keluarga petani, sebagian besar dari mereka adalah perempuan, isteri atau ibu yang juga terlibat. Jumlah perempuan itu sendiri sebanyak 49,66 \% (118 juta lebih), hampir separuh dari jumlah penduduk nasional 237,6 juta, atau hampir seimbang dengan jumlah penduduk laki-laki 50,34\% (119 juta lebih). Dengan demikian Petani perempuan atau petani perempuan menjadi sumberdaya potensial yang perlu dikembangkan lebih lanjut pada sektor pertanian Indonesia.

Mengingat sektor pertanian masih menjadi salah satu sektor yang mendominasi dalam perekonomian Indonesia (Statistik Koperasi, 2005) dan besarnya keterlibatan perempuan pada sektor tersebut, maka pembangunan sektor petanian tidak dapat terlepas dengan pembangunan petani perempuan pada sektor ini. Pengembangan sektor pertanian dalam berbagai lini merupakan salah satu langkah strategis dalam memperbaiki perekonomian Indonesia dan kesejahteraan masyarakat petani khususnya. Dalam hal ini, termasuk didalamnya penciptaan peluang usaha pertanian dan segala hal yang mampu menunjang pembangunan secara berkelanjutan melalui kegiatan produktif yang berguna bagi perkembangan sektor pertanian dan sektor-sektor lain yang terhubung dalam sistem pertanian secara langsung maupun tidak langsung. Dengan demikian pembangunan sektor pertanian akan mampu mendorong perkembangan ekonomi secara merata di seluruh aspek bidang pertanian.

Rendahnya kualitas SDM yang ditunjukkan dengan tingkat pendidikan yang rendah (Bappenas, 2006) dan kemampuan akses informasi pertanian yang minim menjadi tantangan yang besar dalam upaya pembangunan sektor pertanian Indonesia. Minimnya kesempatan bagi petani perempuan pada skala kecil-menengah untuk mengakses informasi dan rendahnya pendidikan yang dimiliki menjadi persoalan dalam meningkatkan kemampuan berinovasi guna mengatasi persoalan yang dihadapi. Berbagai 
persoalan klasik yang senantiasa dihadapi masih menjadi tantangan yang besar bagi pembangunan sektor pertanian yang terus berlangsung seperti siklus tahunan yang tidak bisa dihindari. Menurut Hubeis (1993) pelaksanaan pembangunan pertanian akan berhasil jika semua sumberdaya manusia didalamnya baik laki-laki maupun perempuan tergarap dengan baik. Lebih lanjut dijelaskan bahwa sekitar 78\% dari seluruh penduduk perempuan Indonesia yang tinggal dipedesaan dan lebih dari setengahnya memperoleh nafkah hidup dari sektor pertanian. Dengan dasar inilah peningkatan kapasitas petani perempuan khususnya dalam rangka pembangunan sektor pertanian menjadi sangat dibutuhkan.

Banyak aspek dalam sektor pertanian masih perlu dibenahi. Pembangunan petani perempuan di dalam sektor pertanian dapat menjadi pondasi yang kuat dalam pembangunan pertanian secara berkelanjutan. Rendahnya kemampuan berinovasi sebagai motor pengerak perkembangan pertanian Indonesia pada berbagai lini juga tidak lepas dari persoalan kapasitas petani perempuan di dalamnya yang masih rendah. Hal tersebut nampak dari berbagai potensi pada sektor pertanian yang belum tergarap seperti peran petani perempuan dalam pemanfaatan pekarangan rumah yang bisa dioptimalkan untuk kebutuhan rumah tangga bahkan sampai pada perannya dalam pengelolaan pasca panen melalui inovasi yang menghasilkan produk-produk turunan pertanian yang bernilai jual lebih tinggi. Dalam hal ini, program pemberdayaan petani perempuan menjadi sangat strategis guna meningkatkan kapasitas petani perempuan dan konstribusinya dalam pembangunan sektor pertanian Indonesia . Melalui peningkatan kapasitas inilah akan meningkatkan kemampuan petani perempuan untuki berinovasi dan menjadi motor penggerak pertumbuhan sektor pertanian di Indonesia.

\section{Perempuan dan Potensi Kewirausahaan pada Sektor Pertanian}

Sektor pertanian Indonesia didominasi oleh pertanian skala kecilmenengah yang biasanya identik dengan petani miskin. Kemiskinan dicirikan dengan rendahnya kualitas sumberdaya manusia (Quibria dan Srinivasan, 1993; Sofwani, 1998; dan Tjiptoherijanto, 1998), rendahnya penguasaan aset produktif seperti lahan pertanian (Otsuka, 1993), dan rendahnya aksesibilitas anggota masyarakat terhadap sumber-sumber permodalan dan peluang-peluang ekonomi (Siamwalla, 1993). Dengan demikian sudah semestinya pembangunan pertanian harus berorientasi pada peningkatan produktivitas dan kesejahteraan masyarakat petani.

Ditinjau dari penyerapan tenaga kerja sejumlah penelitian terdahulu menunjukkan bahwa perempuan lebih banyak terlibat dalam sektor kerja informal . Kondisi tersebut menjadi sangat dipahami mengingat peran 
perempuan sebagai ibu rumah tangga sekaligus bekerja membutuhkan fleksibilitas yang lebih tinggi dalam menjalankan pekerjaannya demi mewujudkan keseimbangan perannya. Tuntutan ekonomi rumah tangga yang mendesak seringkali menjadi salah satu alasan perempuan terjun dalam dunia kerja khususnya bagi perempuan yang tinggal di daerah pedesaan. Sektor pertanian dalam kenyataannya menyediakan kesempatan kerja informal yang memberikan kesempatan kepada petani perempuan di pedesaan untuk terlibat didalamnya. Melihat kondisi ini tentunya membutuhkan langkah-langkah yang strategis untuk meningkatkan kapasitas petani perempuan dalam sektor pertanian sehingga dapat mendorong kemampuan menciptakan berbagai peluang usaha sebagai upaya pembangunan pertanian diberbagai lini yang ada.

Sektor pertanian mempunyai potensi kewirausahaan yang sangat besar, hal ini didukung oleh berlimpahkan sumberdaya seperti SDM dan komoditas yang ada pada sektor pertanian. Berbagai potensi lokal tersebut dapat dikembangkan untuk mendukung peningkatan produktivitas sektor pertanian. Tidak hanya potensi yang dimiliki untuk mengembangkan wirausaha berbasis pertanian, lebih lanjut pengembangan usaha pertanian dibutuhkan guna menjaga daya tarik khususnya bagi para petani usia produktif untuk menggarap sektor ini. Sejumlah penelitian sebelumnya menemukan bahwa telah terjadi pergeseran lahan tani setiap tahunnya menjadi pemukiman (Yustika, 2008) dan berpotensi terjadinya pergeseran profesi dari petani menjadi non petani khususnya bagi petani usia produktif pada sektor ini. Kondisi tersebut jika tidak segera diatasi tentu dapat menghasilkan persoalan baru di masa yang akan datang khususnya dalam ketersediaan tenaga kerja petani yang produktif dan potensi kerawanan pangan yang semakin mengancam Indonesia. Perlunya pengembangan kewirausahaan berbasis pertanian pada sektor tersebut menjadi sangat dibutuhkan mengingat potensinya yang dimiliki dan kontribusinya terhadap pembangunan perekonomian Indonesia.

Zakaria menjelaskan bahwa bagian terbesar rumah tangga Indonesia, khususnya di pedesaan kehidupan mereka masih tergantung pada sektor pertanian. Lebih lanjut dijelaskan bahwa pada dasarnya petani berlahan sempit menghadapi permasalahan yaitu tingkat pendapatan yang rendah dan tidak stabilnya pendapatan itu sendiri. Dengan pemahaman tersebut, butuh upaya-upaya untuk peningkatan kesejahteraan keluarga petani dengan meningkatkan kapasitas petani perempuan khususnya dalam menciptakan peluang usaha di bidang pertania melalui berbagai program pelatihan dan pendampingan yang mengarah pada pengembangan IPTEK yang dapat memberikan dorongan terhadap kewirausahaan di bidang pertanian. Binswanger dan Braun (1991) menjelaskan bahwa adanya perubahan teknologi dapat berpengaruh positif terhadap peningkatan pendapatan bagi masyarakat petani berpenghasilan rendah. 


\section{METODE PENELITIAN}

Pendekatan kualitatif melalui metode participation action research digunakan dalam penelitian ini, dimana para peserta dilibatkan secara aktif dalam mengidentifikasi setiap persoalan yang muncul untuk kemudian hasilnya digunakan sebagai informasi dalam mengembangkan program bersama untuk penyelesaian masalah. FGD dilakukan sebagai salah satu sarana untuk mengidentifikasi persoalan dan pencarian solusi secara bersama. Program aksi dirancang secara bersama dimaksudkan untuk membantu mengidentifikasi persoalan yang dihadapi masyarakat petani melalui kegiatan produktif. Dengan demikian setiap program aksi yang dirancang senantiasa diikuti dengan penelitian untuk persoalan yang dihadapi lebih mendalam terhadap persoalan yang dijumpai. Diharapkan melalui pemahaman masalah yang dihadapi maka rancangan program dapat membantu mengatasi persoalan masyarakat petani kecil.

Perancangan program lebih memberikan penekanan pada mengembangkan lifeskill dalam mengatasi persoalan yang dihadapi. Dengan demikian program dirancang untuk memberikan pengalaman praktis bagi para peserta pelatihan. Melalui program tersebut para peserta dapat memperoleh ketrampilan dan pengetahuan yang dibutuhkan untuk mengembangkan wirausaha tani bersama dengan menggunakan potensi lokal yang dimiliki.

\section{HASIL PENELITIAN DAN PEMBAHASAN}

\section{Kapasitas Petani Perempuan dalam Pembangunan Sektor Pertanian}

Hasil kajian yang dilakukan pada para petani perempuan di salah satu desa di wilayah Kabupaten Semarang menunjukkan bahwa peran perempuan dalam aktivitas pertanian sangatlah besar. Mulai dari pekerjaan berat seperti menyiapkan lahan, "nyipuk" atau pembibitan, menanam di lahan, perawatan tanaman sampai dengan masa panen perempuan nyatanya mempunyai peran yang sangat besar. Kegiatan tersebut dilakukan secara periodik di sela-sela peran perempuan sebagai ibu rumah tangga dan sebagai bagian dalam anggota masyarakat. Sebagian besar petani perempuan di desa tidak terjun dalam jenis pekerjaan formal tetapi lebih terlibat dalam pekerjaan informal seperti bertani atau menjadi buruh tani pada musimmusim tertentu. Seperti contohnya banyak perempuan di wilayah ini bekerja sebagai buruh di tetangganya untuk membantu mengolah daun tembakau pada saat musim tembakau. Hal ini dilakukan secara bergilir dan mendapatkan upah atas jasa yang diberikan. Namun demikian pekerjaan sambilan sebagai buruh tani tidak dapat diperoleh setiap waktu. Sebagian besar waktu petani perempuan digunakan untuk mengurus rumah, ternak dan ladang bagi mereka mempunyai lahan dan ternak sendiri. Bagi petani 
yang tidak mempunyai lahan sendiri sebagian besar waktu digunakan untuk mengurus persoalan domestik saja kecuali ada kesempatan menjadi buruh tani pada musim-musim tertentu atau mengurus ternak orang lain untuk bagi hasil yang seringkali disebut "nggadoh". Lebih dari 80\% petani perempuan pada wilayah ini tidak mengenyam pendidikan yang tinggi yaitu rata-rata SD dan maksimal SMP. Tingkat pendidikan yang rendah dan akses informasi yang minim dari para petani perempuan menempatkan mereka pada posisi yang tidak terlalu banyak pilihan untuk terlibat pada sektor formal maupun mendapatkan kesempatan untuk pengembangan kapasitas diri .

Himpitan kebutuhan ekonomi rumah tangga disikapi dengan kesabaran dan kepasrahan terhadap kondisi yang dialami yaitu dengan mencukupkan dengan yang ada atau bahkan berhutang untuk menutup kebutuhan sehari-hari menjadi fenome yang biasa dilakukan. Minimnya penguasaan IPTEK dari para petani perempuan dan rendahnya kemampuan dalam mengakses berbagai informasi berdampak pada rendahnya kapasitas petani perempuan untuk mengatasi persoalan ekonomi rumah tangga. Pentingnya untuk meningkatkan kapasitas petani perempuan menjadi sangat dibutuhkan dalam rangka membantu meningkatkan life-skill mereka khususnya dalam memecahkan persoalan yang dihadapi. Pendidikan yang memberi penekanan pada life-skill dinilai lebih efektif bagi peningkatan kapasitas petani perempuan dalam menyelesaikan masalah yang dihadapi dan meningkatkan kesejahteraan dan produktivitas petani kecil-menengah.

Dalam kajian yang dilakukan baik melalui diskusi mendalam dan observasi pada petani perempuan di wilayah pengamatan, menunjukkan bahwa kemampuan dan kesempatan untuk mengakuisisi pengetahuan dan teknologi oleh petani perempuan masih rendah. Kondisi tersebut nampak pada minimnya IPTEK yang dapat digunakan untuk menghasilkan inovasi produk pertanian dengan nilai yang lebih tinggi. Lebih lanjut, kondisi tersebut berdampak pada rendahnya kemampuan para petani perempuan untuk mengolah pasca panen hasil pertanian mereka menjadi berbagai produk turunan pertanian yang nantinya dapat meghasilkan peluang usaha untuk membantu mengatasi persoalan ekonomi rumah tangga yang dihadapi. Secara umum hasil pertanian berupa sayuran selama ini hanya disetorkan ke tengkulak dengan nilai ekonomisnya yang rendah. Kondisi ini semakin nampak ketika panen raya terjadi dimana komoditas tertentu hampir-hampir tidak mempunyai nilai jual yang bersaing. Sebagai contohnya pada saat musim panen sayur wortel atau tomat, maka komoditas ini hanya mencapai 250 rupiah per kilo. Kondisi ini berlangsung secara terus menerus dan mejadi siklus yang senantiasa terjadi pada saat panen raya. Dalam kondisi tersebut pendekatan yang seringkali digunakan oleh petani kecil adalah dengan memanfaatkan komoditas yang berlimpah untuk dijadikan bahan pakan tambahan bagi ternak mereka. Fenomena tersebut 
menunjukkan bahwa kemampuan untuk berinovasi khususnya dalam mengolah pasca panen masih sangat rendah. Potensi yang besar dalam menghasilkan berbagai produk turunan dari komoditas pertanian masih belum banyak diketahui oleh petani perempuan. Lebih lanjut, pengetahuan yang minim tersebut menyebabkan kemampuan untuk melihat peluang usaha dan berinovasi terhadap komoditas pertanian yang dihasilkan juga sangat rendah .

Selain persoalan pengetahuan, persoalan ketrampilan yang dimiliki oleh petani perempuan juga sangat rendah atau tidak memadai khususnya untuk mengolah produk-produk turunan pertanian sebagai bagian dalam pengelolaan pasca panen. Kondisi tersebut menyebabkan petani perempuan tidak mempunyai kemampuan yang memadai dalam membuat atau mengolah produk-produk turunan pertanian. Fenomena umum yang dijumpai menunjukkan bahwa petani perempuan menggunakan hasil pertanian untuk dijual ke tengkulak atau untuk kebutuhan pangan keluarga bahkan pada saat komoditas terlalu berlimpah hasil tani diberikan kepada ternak sebagai pakan tambahan. Ketrampilan yang dibutuhkan untuk meningkatkan nilai tambah atas komoditas pertanian selama ini belum dapat dimiliki oleh petani perempuan. Minimnya kesempatan untuk meningkatkan ketrampilan petani perempuan melalui pendidikan informal seperti pelatihan pengelolaan pasca panen menyebabkan rendahnya ketrampilan yang dimiliki para petani perempuan dalam menghasilkan produk-produk turunan .

Penguasaan atas pengetahuan dan teknologi dapat menjadi pondasi munculnya berbagai inovasi yang dapat dikembangkan pada sektor pertanian. Meskipun demikian, pengembangan sikap kewirausahaan sangat dibutuhkan untuk mengembangkan sektor pertanian dalam jangka panjang dan berkelanjutan. Budaya lokal mempunyai peran yang besar dalam mengembangkan sikap kewirausahaan. Adanya pandangan bahwa perempuan sebagai "konco wingking" menempatkan posisi perempuan lebih banyak terlibat pada urusan domestik dan meminimalkan perannya dalam memperkuat perekonomian rumah tangga keluarga petani. Kondisi ini tentunya berdampak dalam upaya pengembangan diri dan pembentukan jiwa kewirausahaan yang dimiliki petani perempuan. Gambaran aktivitas petani perempuan di wilayah pengamatan selama ini lebih banyak digunakan untuk mendukung kegiatan pertanian suami dan mengurusi persoalan domestik rumah tangga . Kondisi ini tentunya tidak dapat mengoptimalkan potensi yang besar yang dimiliki petani perempuan dalam sektor pertanian. Minimnya kesempatan yang dimiliki oleh petani perempuan untuk mengembangkan kapasitas diri mempunyai dampak yang besar dalam mengembangkan jiwa kewirausahaan para petani perempuan dan perannya dalam perkembangan sektor pertanian. Pengembangan sikap mental petani perempuan dalam mengembangkan 
jiwa kewirausahaan antara lain seperti dibutuhkannya sikap disiplin yang tinggi, motivasi yang besar untuk belajar dan berkembang, keberanian untuk mengambil peluang yang ada serta sikap mental pantang menyerah. Namun demikian fenomena yang dijumpai menunjukkan bahwa sikap yang dibutuhkan untuk mengembangkan jiwa kewirausahaan para petani perempuan masih butuh dikembangkan dengan optimal. Lebih lanjut rendahnya kreativitas yang dibutuhkan dalam mengatasi persoalan dan dibutuhkan dari seorang wirausaha belum dimiliki. Fenomena yang sering dijumpai salah satunya adalah bagaimana mengatasi persoalan panen raya melalui kreativitas petani perempuan dalam menghasilkan produk-produk turunan pertanian yang masih rendah.

Minimnya kapasitas petani perempuan dalam sektor pertanian lebih lanjut berdampak pada lemahnya aspek kelembagaan yang ada. Kondisi tersebut menjadi kendala yang besar dalam perkembangan wirausaha berbasis pertanian di Indonesia. Keterlibatan yang tinggi petani perempuan dalam organisasi kecil yang dikembangkan di wilayah kajian nyatanya belum diimbangi dengan kemampuan petani perempuan untuk mengelola dan mengembangkan kapasitas bersama. Keterlibatan petani perempuan dalam kelembagaan yang ada nampak ketika petani perempuan terlibat di banyak organisasi kecil yang dikembangkan seperti tabungan "lawuhan", tabungan "saparan" dan sejenisnya. Hampir disetiap minggu petani perempuan mengambil bagian dalam kegiatan tersebut dan mengembangkan aturan yang disepakati bersama. Namun demikian, adanya potensi dari aspek kelembagaan yang ada nyatanya belum diimbangi dengan kemampuan mengelola dengan baik. Dari organisasi kecil yang dikembangkan, aktivitas utama lebih diarahkan pada kegiatan simpan pinjam untuk kebutuhan sehari-hari atau untuk perayaan hari saparan dan sejenisnya dan belum mengarah pada kegiatan produktif dalam rangka meningkatkan kapasitas dan kesejahteraan bersama.

\section{Pengembangan Kapasitas Petani Perempuan Secara Bersama melalui Wirausaha Tani Berbasis Kelompok}

Kapasitas petani perempuan sangat dibutuhkan dalam rangka pengembangan organisasi kemasyarakatan menjadi sarana untuk meningkatkan kapasitas petani perempuan secara bersama. Pemahaman akan arti penting membangun kebersamaan melalui kegiatan produktif yang diwadahi dalam kerangka organisasi relatif masih rendah. Sebagai contohnya kegiatan tabungan saparan digunakan sebatas untuk kegiatan simpan-pinjam baik untuk menutup kebutuhan sehari-hari atau untuk mempersiapkan perayaan saparan yang membutuhkan banyak biaya untuk pengadaan berbagai lauk pauk dan jajanan. Adanya potensi dari keterlibatan petani perempuan dalam organisasi, komoditas yang dihasilkan dan budaya lokal yang mendukung belum sepenuhnya ditangkap sebagai 
peluang usaha berbasis pertanian. Kondisi ini menjadi gambaran umum yang dapat dijumpai di sektor pertanian. Masih rendahnya pemahaman dan kesadaran akan pentingnya berorganisasi untuk membangun kapasitas dan kekuatan bersama menyebabkan organisasi yang sudah ada belum mampu diarahkan dan dikembangkan menjadi kelompok usaha tani bersama.

Berbagai program yang dikembangkan untuk dapat meningkatkan kapasitas petani perempuan dan penguatan kelembagaan masih minim didapatkan bagi para petani perempuan di wilayah pengamatan. Kondisi ini lebih lanjut berdampak pada banyaknya potensi lokal yang belum tergarap dengan optimal. Berbagai komoditas yang dihasilkan belum dapat diolah guna mendukung perekonomian dan kesejahteraan keluarga petani kecil-menengah. Sejumlah komoditas sayuran seperti cabe, tomat, ketela, dan sayuran hijau lain dihasilkan dan disetorkan kepada tengkulak baik yang difasilitasi oleh penduduk sekitar ataupun dari luar. Rendahnya kapasitas petani perempuan menjadi kendala dalam meningkatkan nilai jual atas komoditas yang dihasilkan. Kondisi inilah yang berkontribusi pada munculnya persoalan panen raya yang belum bisa teratasi dengan baik dan menjadi persoalan klasik pada sektor pertanian. Berdasarkan hasil kajian di wilayah pengamatan, ketela merupakan salah satu jenis tanaman yang selalu ditanam sepanjang musim di wilayah pengamatan, penanaman ketela dilakukan selain untuk mengisi kekosongan lahan, penanaman ketela juga biasanya dimanfaatkan untuk makanan sampingan bagi ternak sapi mereka. Dengan demikian tanaman ketela merupakan salah satu komoditas yang dimiliki karena hampir disepanjang musim selalu dapat diperoleh ketela tanpa kesulitan. Selain modal yang rendah dalam menanam ketela untuk perawatannya juga relatif mudah. Namun demikian, komoditas ketela yang dimiliki selama ini masih belum diolah dengan optimal. Berbagai inovasi yang ada untuk mengolah ketela menjadi berbagai produk turunan seperti wingko ataupun jajanan kecil dari ketela masih belum bisa dihasilkan. Demikian halnya untuk komoditas lain seperti cabe yang dapat diolah lebih lanjut menjadi abon cabe atau cabe kering, tomat menjadi kurma tomat dan saos tomat, sayuran hijau menjadi nugget sayur, ataupun produk turunan lain atas komoditas lokal yang dimiliki. Berbagai inovasi untuk menghasilkan produk turunan tentunya membutuhkan kapasitas petani perempuan yang lebih memadai melalui peningkatan pengetahuan, ketrampilan dan sikap mental yang mendukung kewirausahaan dalam rangka pembangunan sektor pertanian. Adanya tradisi lokal seperti saparan memberikan peluang tersendiri bagi petani perempuan melalui pengembangan wirausaha tani bersama untuk menghasilkan berbagai produk turunan yang benrilai jual lebih tinggi. Dengan demikian, peningkatan kapasitas petani perempuan menjadi kebutuhan utama dalam mengembangkan wirausaha tani berbasis kelompok. 


\section{KESIMPULAN DAN PENUTUP}

Peningkatan kapasitas petani perempuan melalui pendidikan informal yang lebih diarahkan pada peningkatan life-skill menjadi kebutuhan khususnya untuk meningkatkan peran petani perempuan dalam pembangunan sektor pertanian dalam jangka panjang dan berkelanjutan. Hal tersebut dapat diwujudkan melalui peningkatan akses dan kesempatan untuk mendapatkan pelatihan kewirausahaan berbasis kelompok tani melalui pembuatan produk turunan pertanian dapat memberikan pengetahuan dan ketrampilan bagi para petani perempuan untuk dapat mengembangkan dan meningkatkan kapasitas para petani kecil khususnya petani perempuan dalam mengatasi persoalan ekonomi yang dihadapi. Program peningkatkan life-skill ini dirancang untuk dapat meningkatkan kemampuan mengatasi persoalan yang dihadapi petani perempuan. Melalui peningkatan akses ilmu pengetahuan dan teknologi yang sudah banyak dikembangkan dapat membantu dalam meningkatkan kemampuan untuk berinovasi.

Program pelatihan dan pendampingan dapat memberikan penekanan pada pembentukan sikap dan mental untuk membangun wirausaha di bidang pertanian. Pengembangan sikap disiplin, pantang menyerah, keinginan untuk belajar dan kesabaran yang tinggi dalam merintis usaha baru menjadi modal yang kuat untuk keberlangsungan sebuah usaha bersama. Selain peningkatan pengetahuan dan ketrampilan dalam mengelola pasca panen melalui pembuatan produk turunan pertanian, para petani perempuan juga dibekali dengan kemampuan dalam mengembangkan wirausaha tani bersama. Hal ini dilakukan agar para petani perempuan dapat mengembangkan kapasitas bersama melalui berorganisasi dalam rangka merintis usaha tani bersama. Selama ini para perempuan sudah terlibat dalam berabgai kegiatan keorganisasian tetapi sebagian besar belum memberi dorongan atau arahan pada kegiatan produktif bersama untuk peningkatan kesejahteraan bersama.

Berbagai pelatihan dan pendampingan yang mengarah pada peningkatan life-kill petani perempuan di pedesaan tentunya dapat menjadi model pemberdayaan yang baik bagi kelompok-kelompok tani khususnya bagi para petani perempuan skala kecil-menengah dalam meningkatkan kapasitas mereka dan peran mereka dalam perekonomian keluarga petani. Mengingat secara makro gambaran petani di Indonesia adalah tidak jauh dari potret kemiskinan sehingga melalui program ini juga dapat memberikan kontribusi bagi pengentasan kemiskinan di Indonesia kedepan. 


\section{Daftar Pustaka}

Bougrain, F and Haudeville, B. 2002. Innovation, collbaoration and SMEs internal research capacities, Research Policy 31, 735-748

Danse, Myrtille \& Sietze Vellema, Sietze. 2007. Small-scale Farmer Access to International Agri-food Chains A BOP-Based Reflection on the Need for Socially Embedded Innovation in the Coffee and Flower Sector http://www.greenleaf-publishing.com/productdetail. kmod?productid $=2568$.

Freel, Marks S and Harrison, Richard T. 2006. Innovation and Cooperation in the Small Firm Sector: Evidence from 'Nothern Britain'. Regional Studies, vol 40.4.

Huggins, R. 2001. Inter-Firm network policies and firm performance: evaluating the impact of initiatives in the United Kingdom. Research Policy 30, 443-458.

Kasryno, F. dan A. Suryana. 1992. “Long Term Planning for Agricultural Development Related to Provert Alleviation in Rural Areas". Dalam: Pasandaran, E. et al. (ed). Proverty Allevation With Sustainable Agricultural and Rural Development in Indonesia Proceeding of National Seminar and Workshop. Bogor, January 7th-10th, 1992. pp. 60-76.

Laine Mikko O.J \& Laine, Antti V.O. Open innovation, Intellectual Capital and Different Knowledge Source. Proceedings of the European Conference on Intellectual Capital is the property of Academic Conferences, Ltd.

Laderman, Daniel and Saenz, Laura. Innovation and Development around the World 1960-2000. Research Policy Workking Paper 3774, November 2005

Lu, Shu-Ling dan Sexton, Martin. 2006 Innovation in Small Construction Knowledge-Intensive Profession Service Firm: A Case Study of an Architectural Practice. Construction Management and Economics. Vol 24, p 1269-1282.

Lukman M Baga. 2005. Penguatan Kelembagaan Koperasi Petani untuk Revitalisasi Pertanian 1. MITI. Jakarta.

Ningsih, Diah Ayu. 2009. http://diahayuningsih.wordpress.com/

Rahman, Taufiqur M. 2013. http://m.bisnis.com/industri/read/20131205/99/ 190760/nilai-tukar-petani-cenderung-stagnan.

Romano, Claudio A. 1990. Identifying Factors Wich Influence Product Innovation: A Case Study Approach. Journal of Management Studies. 
Sikhondze, wilson b. 1999. The Role of Extension in farmer Education and Information Dissemination in Swaziland, Journal: Edult Education and Development No. 53/1999, Institute for International Cooperation of The German Adult Education Association, Bonn: 112/DVV.

Sulaiman, V Rasheed; Thummuru, Laxmi; Hall, Andy and Dijkman, Jeroen.2011. Tacit Knowledge and Innovation capacity: evidence from the Indian livestock sector. Knowledge Management for Development Journal Vol. 7, No. 1, May 2011, 32-44.

Sumaryanto. 2002. "Masalah Pertanahan di Indonesia dan Implikasinya Terhadap Tindak Lanjut Pembaharuan Agraria". Paper. Puslitbang Sosek Pertanian Badan Litbang Pertanian.

Suradisastra, Kedi. 2006. Pemanfaatan lembaga Untuk Pembangunan Sektor Pertanian Mendukung Otonomi Daerah. Badan Penelitian dan Pengembangan Pertanian

Setiarso, Bambang. 2003. Pendekatan "Knowledge-Base Economy" untuk Pengembangan Masyarakat. Komunitas eLearning IlmuKomputer.com 